\title{
Relationship Between Length of Exposure to Trauma and Mental Illness in the Police
}

\begin{abstract}
Keywords: Deployment; Police; Military personnel; Mental disorders; Combat disorders
\end{abstract}

\begin{abstract}
Introduction: The activities of the police are considered high risk, because they are exposed to high levels of physical and emotional stress. These work activities can contribute to the emergence of psychiatric disorders that affect their readiness in responding to threats and safety of their actions. Our aim was to conduct a systematic literature review to identify studies that evaluated the time that police officers may be deployed without developing a mental illness.

Materials and methods: Articles published until May 2016 in The MEDLINE (PubMed), Cochrane Library, PsycINFO, and Lilacs databases were searched. In addition, a manual search in the gray literature (theses and dissertations) was also conducted. Several combinations of indexed terms were used in the search of electronic databases, including terms referring to trauma exposure, intervention, and population. There were no restrictions on date and language of the publications. Two reviewers independently assessed studies for eligibility and quality. Disagreements were resolved after consultations with a third reviewer.
\end{abstract}

Results: Of 905 selected studies, 13 studies evaluated deployment duration and the incidence of mental illness. Studies were excluded because they addressed the prevalence of mental illness but did not relate it to deployment duration or because the studied sample was not the target population of the present study. Studies have shown that a longer deployment time is associated with increased incidence of mental illness. Our analysis of the 13 identified studies indicated the existence of an association between exposure to deployment and mental illness onset.

Conclusion: These findings will be useful to inform and guide future studies conducted in Brazil and worldwide.

\section{Introduction}

Previous studies have shown that soldiers may develop PostTraumatic Stress Disorder (PTSD) after deployment, and the prevalence of stress has increased among deployed soldiers, with those exposed to more intense activities developing higher rates of mental illness [1-4]. The Harmony Guidelines recommend that soldiers should be redeployed every 6 months and should be deployed for no more than 12 months in a period of 36 months. They also state that health problems increase with deployment duration [5-7].

Armed conflicts have characteristics that lead to harmful longterm effects on the health of military personnel, even after they return to civilian life [8,9]. In addition, soldiers generally exhibit higher levels of depression, anxiety, and work-related stress than civilians [10]. However, few studies have addressed the physical and mental health status of police officers, and most of the published studies describe only their daily routines [11-14]. Furthermore, the effects of PTSD are a major concern among decision makers, police officers, and

\section{Journal of}

Neurology and Psychology

\section{Santiago Bossert $\mathrm{TC}^{1^{*}}$, Guerra Júnior, $\mathrm{AA}^{2}$, Ruas $\mathrm{CM}^{2}$, de Araújo $\mathrm{VE}^{2}$, de Assis Acúrcio $\mathrm{F}^{2}$, Godman $B$ and Bennie $\mathbf{M}^{3}$}

${ }^{\prime}$ Military Police Hospital of Minas Gerais, Brazil

${ }^{2}$ Federal University of Minas Gerais, Brazil

${ }^{3}$ Strathclyde Institute of Pharmacy and Biomedical Sciences, University of Strathclyde, UK

*Address for Correspondence

Tatiana Caroline Santiago Bossert, Military Police Hospital of Minas Gerais, StreetPacífico Mascarenhas, Santa Efigência, Cep 30110013, Belo Horizonte, MG,Brazil, Tel: 5531992776252; E-mail: tatianabossert@yahoo.com.br

Submission: October 24, 2018

Accepted: April 05, 2019

Published: April 09, 2019

Copyright: ๑ 2019 Santiago Bossert TC, et al. This is an open access article distributed under the Creative Commons Attribution License, which permits unrestricted use, distribution, and reproduction in any medium, provided the original work is properly cited.

policymakers [15]. Mental illness can compromise the performance of police officers, in terms of their attention and response readiness in performing their duties and responsibilities. Understanding the relationship between the length of exposure to work-related trauma and the occurrence of mental illness contributes to the planning of measures aimed at optimizing the management of military personnel and health care among police officers.

Given the lack of information on deployment duration among police officers, studies that explore these data in more depth are necessary to develop programs targeted at protecting the mental health of police officers who are directly involved in combat.

Using a systematic review, this study aimed to address this deficit by assessing the scientific evidence on the relationship between length of exposure to trauma and mental illness in military personnel. The findings will be used to suggest future government programs both in Brazil and worldwide.

\section{Methods}

This review was conducted in accordance with the recommendations of the manual for systematic reviews and metaanalyses of observational studies in epidemiology (MOOSE) [16].

\section{Eligibility criteria}

This review included observational studies (cohort, case-control, or cross-sectional) that evaluated the length of deployment of police officers of both sexes who developed mental illnesses, such as PTSD and depression. Date and language of publication were not considered as exclusion criteria.

\section{Study search}

A systematic review was conducted by including studies that were published until May 2016. A search of the journals indexed in MEDLINE (PubMed), Latin American and Caribbean Health Sciences Literature (LILACs), Cochrane Library, and PsycINFO was 
Citation: Santiago Bossert TC, Guerra Júnior, AA, Ruas CM, de Araújo VE, de Assis Acúrcio F, et al. Relationship Between Length of Exposure to Trauma and Mental IIIness in the Police. J Neurol Psychol. 2019; 7(1): 11.

ISSN: $2332-3469$

Table 1: Bibliographic search conducted in May 2016 to identify relevant studies.

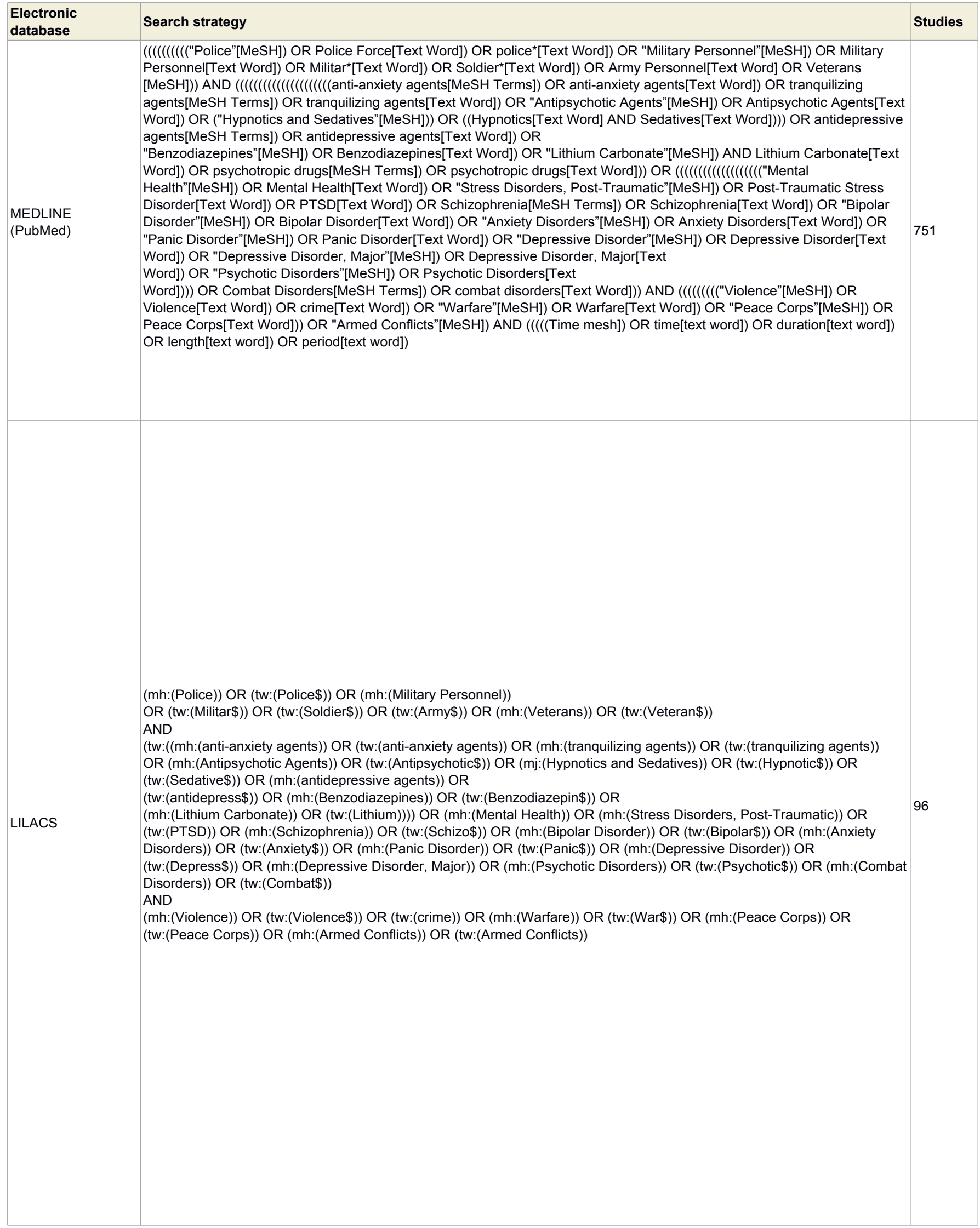


Citation: Santiago Bossert TC, Guerra Júnior, AA, Ruas CM, de Araújo VE, de Assis Acúrcio F, et al. Relationship Between Length of Exposure to Trauma and Mental IIIness in the Police. J Neurol Psychol. 2019; 7(1): 11.

\begin{tabular}{|c|c|c|}
\hline $\begin{array}{l}\text { COCHRANE } \\
\text { LIBRARY }\end{array}$ & 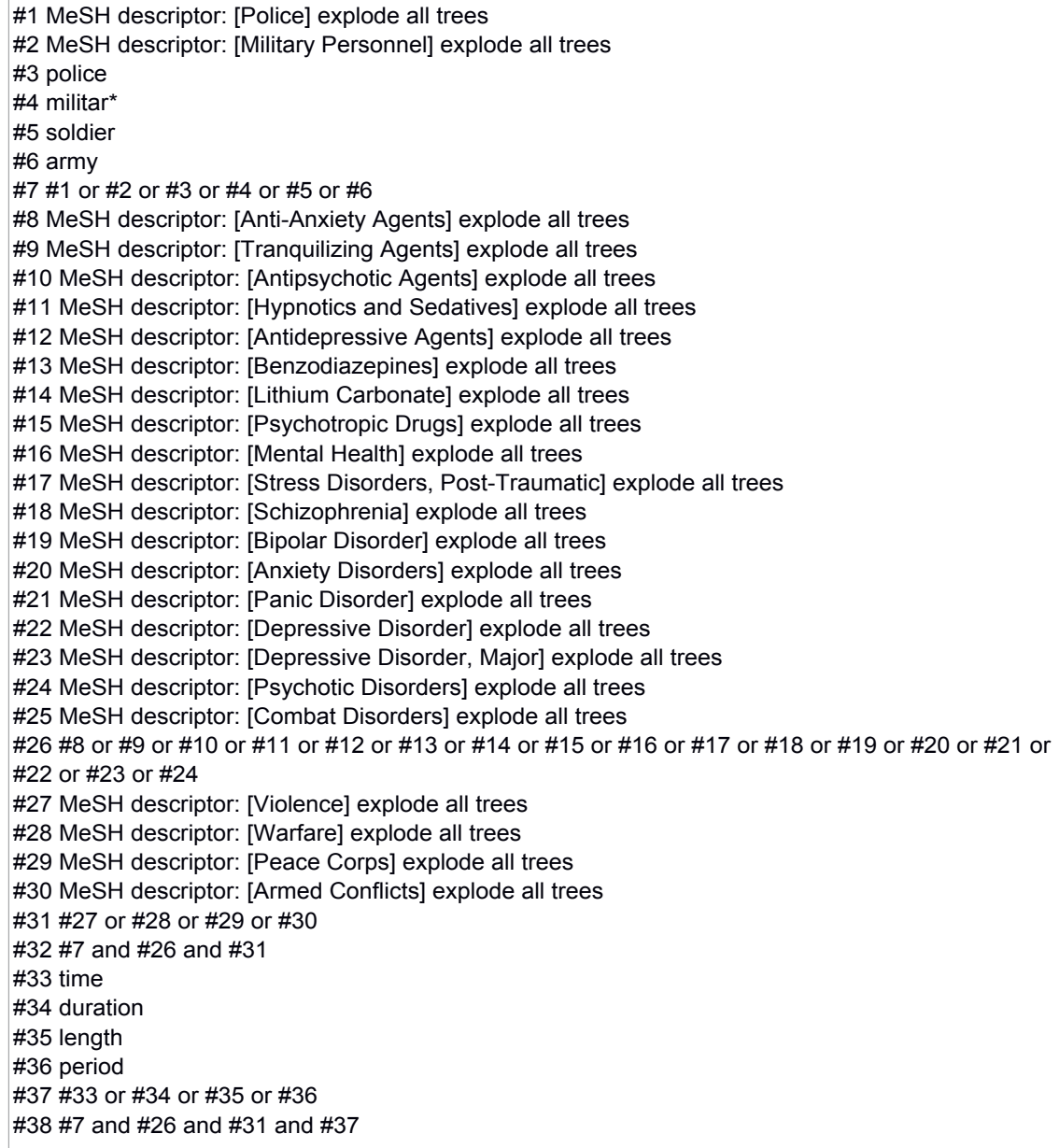 & 18 \\
\hline PSYCHO INFO & $\begin{array}{l}\text { (Violence or Warfare or Peace Corps or Armed Conflicts) } \\
\text { AND (Police or police* or military* or soldier or } \text { army }^{*} \text { or veteran*) }\end{array}$ & 48 \\
\hline
\end{tabular}

Table 2: General characteristics of the included studies.

\begin{tabular}{|c|c|c|c|c|c|c|c|}
\hline Study & $\begin{array}{c}\text { Type of } \\
\text { organization }\end{array}$ & Participants & Combat site & Type of illness & Data collection & Study duration & Study design \\
\hline $\begin{array}{l}\text { Clarke et } \\
\text { al. }(2015)^{9}\end{array}$ & $\begin{array}{c}\text { Australian Army, } \\
\text { Navy, and Air } \\
\text { Force }\end{array}$ & $\begin{array}{c}60228 \text { (cases) } \\
82877 \text { (control) }\end{array}$ & Vietnam & $\begin{array}{l}\text { Mental illnesses } \\
\text { and disabilities }\end{array}$ & Data logging & $\begin{array}{l}\text { May } 1962 \text { and } \\
\text { April } 1975 \\
\text { (cases) } 1972 \\
\text { and } 1994 \\
\text { (control) }\end{array}$ & Historical cohort \\
\hline $\begin{array}{c}\text { Brundage } \\
(2013)^{17}\end{array}$ & $\begin{array}{l}\text { United States } \\
\text { Armed Forces }\end{array}$ & 154548 & $\begin{array}{c}\text { Iraq and } \\
\text { Afghanistan }\end{array}$ & $\begin{array}{c}\text { Mental diseases } \\
\text { among other } \\
\text { diseases }\end{array}$ & $\begin{array}{l}\text { Post-deployment } \\
\text { experiences } \\
\text { of all female police } \\
\text { officers }\end{array}$ & $\begin{array}{l}\text { October } 1 \text {, } \\
2001 \text { through } \\
\text { December } 31 \text {, } \\
2010\end{array}$ & Cohort \\
\hline $\begin{array}{l}\text { Bell et al. } \\
(2011)^{18}\end{array}$ & United States Army & 4457 & $\begin{array}{l}\text { Diverse combat } \\
\text { zones, including } \\
\text { declared wars, } \\
\text { police actions, and } \\
\text { peace missions. }\end{array}$ & $\begin{array}{l}\text { Mental illnesses } \\
\text { and other } \\
\text { disabilities (other } \\
\text { than mental } \\
\text { disabilities) and } \\
\text { no disabilities. }\end{array}$ & Database & $\begin{array}{l}\text { January } 1994 \text { to } \\
\text { December } 2007\end{array}$ & Case-control \\
\hline
\end{tabular}


Citation: Santiago Bossert TC, Guerra Júnior, AA, Ruas CM, de Araújo VE, de Assis Acúrcio F, et al. Relationship Between Length of Exposure to Trauma and Mental IIIness in the Police. J Neurol Psychol. 2019; 7(1): 11.

ISSN: $2332-3469$

\begin{tabular}{|c|c|c|c|c|c|c|c|}
\hline AFHSC $(2011)^{19}$ & $\begin{array}{l}\text { United States } \\
\text { Armed Forces }\end{array}$ & 1347731 & $\begin{array}{c}\text { Iraq and } \\
\text { Afghanistan }\end{array}$ & $\begin{array}{l}\text { Mental illnesses } \\
\text { (ICD-9), among } \\
\text { other diseases }\end{array}$ & $\begin{array}{l}\text { Post-deployment } \\
\text { experiences }\end{array}$ & $\begin{array}{l}\text { October } 1 \text {, } \\
2001 \text { to } \\
\text { December } 31 \text {, } \\
2010\end{array}$ & Cohort \\
\hline $\begin{array}{l}\text { MacGregor } \\
(2014)^{20}\end{array}$ & United States Navy & 3512 & $\begin{array}{c}\text { Afghanistan, Kuwait, } \\
\text { and Iraq }\end{array}$ & PTSD & $\begin{array}{l}\text { Health screening } \\
\text { questionnaire to } \\
\text { identify health } \\
\text { problems in personnel } \\
\text { returning from } \\
\text { deployments. }\end{array}$ & $\begin{array}{l}\text { *January } 2005 \text { to } \\
\text { December } 2008\end{array}$ & Historical cohort \\
\hline $\begin{array}{l}\text { O'Toole et } \\
\text { al. }(2009)^{21}\end{array}$ & $\begin{array}{l}\text { Australian } \\
\text { Veterans }\end{array}$ & $\begin{array}{c}450 \text { veterans } \\
\text { compared to the } \\
\text { general population }\end{array}$ & Vietnam & $\begin{array}{l}\text { Psychiatric } \\
\text { diagnoses } \\
\text { described in } \\
\text { ICD-10 }\end{array}$ & $\begin{array}{l}\text { Interviews conducted } \\
\text { through standard } \\
\text { questionnaires }\end{array}$ & $\begin{array}{c}\text { July } 1990 \\
\text { through } \\
\text { February } \\
1993 \text { and April } \\
2005 \text { through } \\
\text { November } 2006\end{array}$ & Prospective cohort \\
\hline $\begin{array}{l}\text { Shen et al. } \\
(2009)^{22}\end{array}$ & United States Navy & 112720 & $\begin{array}{c}\text { Iraq and } \\
\text { Afghanistan }\end{array}$ & PTSD & Database & $\begin{array}{c}\text { * October } 2002 \\
\text { to December } \\
2015\end{array}$ & $\begin{array}{l}\text { Retrospective } \\
\text { cohort }\end{array}$ \\
\hline $\begin{array}{l}\text { Okulate et al. } \\
\qquad(2006)^{23}\end{array}$ & Nigerian Army & 1131 & $\begin{array}{l}\text { Liberia and Sierra } \\
\text { Leone }\end{array}$ & PTSD & $\begin{array}{l}\text { Interviews conducted } \\
\text { through standard } \\
\text { questionnaires }\end{array}$ & $\begin{array}{c}{ }^{*} \text { Four-year } \\
\text { period }(1990- \\
1994)\end{array}$ & Historical cohort \\
\hline Adler $(2005)^{7}$ & $\begin{array}{l}\text { United States } \\
\text { Army, Navy, } \\
\text { Air Force, and } \\
\text { Marines. }\end{array}$ & 3339 & $\begin{array}{l}\text { Bosnia and } \\
\text { Herzegovina, } \\
\text { Hungary, and } \\
\text { Croatia }\end{array}$ & $\begin{array}{l}\text { PTSD and } \\
\text { depression }\end{array}$ & $\begin{array}{l}\text { Psychological } \\
\text { screening } 30 \text { days } \\
\text { before returning to } \\
\text { the original combat } \\
\text { location. }\end{array}$ & $\begin{array}{c}\text { February } 1996 \\
\text { to September } \\
1999\end{array}$ & Cross-sectional \\
\hline $\begin{array}{l}\text { Grieger et al. } \\
\qquad(2006)^{24}\end{array}$ & $\begin{array}{c}\text { Soldiers of the } \\
\text { United States Army }\end{array}$ & 613 & $\begin{array}{c}\text { Iraq and } \\
\text { Afghanistan }\end{array}$ & $\begin{array}{l}\text { PTSD and } \\
\text { depression }\end{array}$ & $\begin{array}{c}\text { Soldiers were } \\
\text { reassessed after } 4 \\
\text { and } 7 \text { months, either } \\
\text { by telephone interview } \\
\text { or after returning to } \\
\text { hospital for outpatient } \\
\text { treatment. }\end{array}$ & $\begin{array}{l}\text { * March } 2003 \text { to } \\
\text { September } 2004\end{array}$ & Longitudinal cohort \\
\hline $\begin{array}{l}\text { Emsley, et al. } \\
\qquad(2003)^{25}\end{array}$ & $\begin{array}{l}\text { South African } \\
\text { Security Forces }\end{array}$ & 124 & South Africa & PTSD & $\begin{array}{l}\text { Patients' interview and } \\
\text { history records were } \\
\text { assessed from } \\
\text { records }\end{array}$ & $\begin{array}{c}\text { January } 1996 \text { to } \\
\text { March } 1999\end{array}$ & Case-control \\
\hline $\begin{array}{l}\text { Ross and } \\
\text { Wonders } \\
(1993)^{26}\end{array}$ & $\begin{array}{l}\text { US Army, Navy, } \\
\text { and Air Force }\end{array}$ & $\begin{array}{l}234 \text { cases } 15 \\
\text { controls }\end{array}$ & Saudi Arabia & $\begin{array}{l}\text { Mental illnesses } \\
\text { (ICD-9), among } \\
\text { other diseases }\end{array}$ & $\begin{array}{l}\text { Two interviews through } \\
\text { the application of } \\
\text { questionnaires, }\end{array}$ & $\begin{array}{c}\text { October } 1 \text {, } \\
2001 \text { to } \\
\text { December } 31 \text {, } \\
2010\end{array}$ & Historical cohort \\
\hline $\begin{array}{l}\text { Branchey } \\
(1990)^{27}\end{array}$ & $\begin{array}{l}\text { United States } \\
\text { Veterans }\end{array}$ & 84 & Vietnam & PTSD & $\begin{array}{l}\text { Interviews conducted } \\
\text { through standard } \\
\text { questionnaires }\end{array}$ & $\begin{array}{c}\text { 1955-1975 } \\
\text { (Vietnam War) }\end{array}$ & Historical cohort \\
\hline
\end{tabular}

* Period of data collection

conducted using the parameters described in the eligibility criteria. Strategies were developed specifically for each database and $\mathrm{MeSH}$ descriptors were used (Table 1).

To identify any relevant studies published and not retrieved through the initial search strategy, a manual search was conducted of the bibliographic references of selected studies and available systematic reviews. The Brazilian thesis database (Capes) (http:// www.capes.gov.br/servicos/banco-de-teses) was also searched.

\section{Study Selection and Data Collection}

The search criteria were applied to titles and abstracts. The studies retrieved from the electronic databases were collected on a single basis to exclude duplicates. The articles were evaluated by pairs of independent reviewers in two phases: (i) titles/abstracts of identified studies and (ii) complete reading of selected texts. Cases of disagreement between the reviewers regarding the inclusion of the study in the present review were assessed by a third reviewer. Data were collected in duplicate in a previously tested Excel spreadsheet developed for this purpose (Tables 2 and 3 ).

\section{Assessment of methodological quality}

The methodological quality of each study was assessed by two examiners, and the divergences were resolved by consensus. For this 
Citation: Santiago Bossert TC, Guerra Júnior, AA, Ruas CM, de Araújo VE, de Assis Acúrcio F, et al. Relationship Between Length of Exposure to Trauma and Mental Illness in the Police. J Neurol Psychol. 2019; 7(1): 11.

purpose, the Newcastle-Ottawa Scale was used for the observational studies, as recommended by the Cochrane Collaboration. This scale judges studies on three major domains: study group selection, group comparability, and assessment of exposure and outcomes of interest. The maximum total score is nine, and scores above six are indicative of quality, as shown in (Table 4). For cross-sectional studies, the methodological quality was not assessed, as this evaluation has not been validated for this type of study.

\section{Results}

The total number of articles retrieved from electronic databases was 905. The primary exclusion criteria for studies were those that referred to the prevalence of mental illness, specific mental illnesses, combat characteristics, or population that were not those of interest. These articles were excluded from the analysis because they did not meet the objectives of this review. After eliminating such studies, 50 studies were selected for complete reading. After this, only 13 studies met all the inclusion criteria and were thus included in the analysis (Figure 1).

Tables 2-4 present information on the general characteristics, main results, and quality assessment of the included studies.

The total of 13 studies included, cohort studies $(n=8)$, casecontrol studies $(n=2)$, and cross-sectional studies $(n=3)$ studies. The studies by $[17,18]$, and assessed secondary data. The studies by used questionnaires as instruments [19-26]. Used both secondary and questionnaire data. The duration of the studies ranged from 3 to 36 years [27] (Table 2).

In total, 1,689,171 records, interviews, or database entries concerning the association between the exposure of police officers to combat and mental illness were evaluated in the 13 studies included in this review. The total number of records per study ranged from 84 to $1,347,731$ (Table 2).

The studies included police officers from four different countries: Australia, United States, Nigeria, and South Africa. The types of organizations included were armed and security forces as well as veteran organizations (Table 2). In relation to the mental illnesses studied, five articles studied only PTSD, whereas the other articles studied mental illness and other disabilities (Table 2).

All studies included in this review assessed the time of exposure to combat. Although no filter for the type of police was used, all the retrieved studies were related to war military personnel, and the exposure to combat was termed deployment, which is defined as overt confrontation. The studies by AFHSC (2011) and MacGregor et al. (2014) evaluated the "dwell time," which is the time between deployments (Table 3 ).

Most studies have shown that the longer the deployment, the higher the frequency of mental illnesses. demonstrated that PTSD is lower from the fourth deployment onwards (Table 3).

Okulate and Jones (2006) showed that PTSD was significantly associated with the time spent in the combat area $\left(\chi^{2}=60.93, \mathrm{p}<\right.$ $0.00)$. Emsley et al. (2003) showed that $18 \%$ of the individuals who reported a delay in symptom onset following exposure to trauma had significantly longer police service time (Table 3 ).
O'Toole et al. (2009) conducted two sets of interviews with Australian veterans, 21.96 and 36.2 years after the mission. They observed that the association of deployment with moderate depressive disorders and PTSD diagnosis was higher in the first set of interviews than in the second. Ross and Wonders (1993) found that deployments of more than six months decreased PTSD scores. also observed that PTSD was lower in the fourth and fifth deployments than in the third deployment. found that exposure to combat was not significantly associated with the risk of PTSD or depression at four or seven months (Table 3 ).

With regard to dwell time, and reported that the number of deployed individuals who were diagnosed with PTSD and anxiety disorders increased with the dwell time that preceded the second of three deployments when compared with the length of the first deployment; the dwell time was, on average, longer than the duration of the first deployment, with a median of 338 days (Table 3 ).

The cohort studies included 60,228 police officers and 450 Australian veterans, respectively, with Vietnam as the combat site. In the first study, 82,877 police officers were compared with the sample, and the second study used the total population for comparison. The first study lasted three years and the second study lasted $21.96 \pm 1.91$ and $36.10 \pm 1.92$ years after the return to Australia; the latter study had one limitation, which was the potential loss of information in interviews conducted many years after the events.

Regarding quality assessment, of the 10 studies analyzed, one study reached the highest score on the Newcastle-Ottawa scale, i.e., nine points; five studies obtained seven points; one study obtained six points; one study had five points; one study obtained four points; and one study received three points. Therefore, only the following six studies included in this review received a good quality score: (Table 4).

The studies by associated PTSD incidence with duration of service; the longer the duration of service exposed to trauma, the longer the delay in relation to the onset of PTSD-related symptoms.

The studies differ in terms of population and objectives. The older study included all police officers in the United States, whereas the more recent included only female police officers. The first study aimed to assess deployment and dwell time experiences. The second

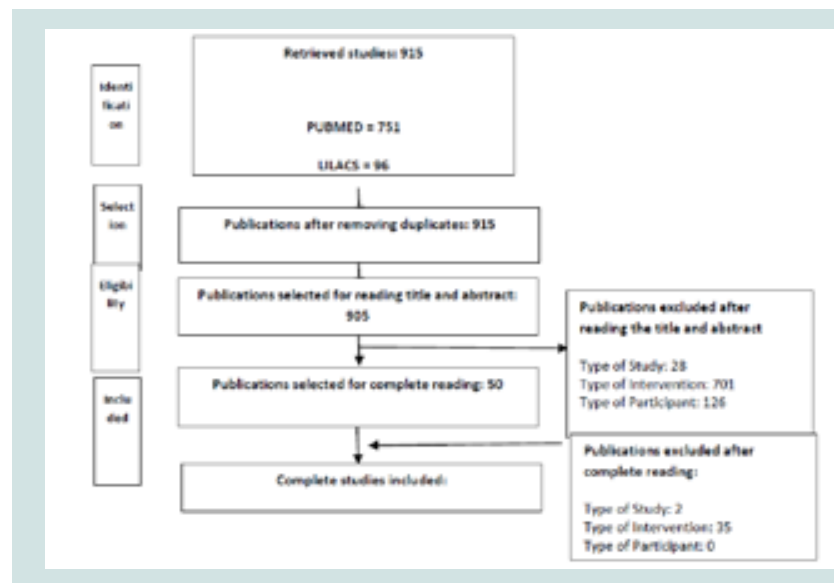

Figure 1: Flowchart of the selection of studies for the systematic review. 
Citation: Santiago Bossert TC, Guerra Júnior, AA, Ruas CM, de Araújo VE, de Assis Acúrcio F, et al. Relationship Between Length of Exposure to Trauma and Mental IIIness in the Police. J Neurol Psychol. 2019; 7(1): 11.

ISSN: 2332-3469

Table 3: Information and results of the studies evaluated.

\begin{tabular}{|c|c|c|c|c|}
\hline Study & Objectives of the study & $\begin{array}{l}\text { Diagnosis } \\
\text { Methods }\end{array}$ & Population/sample & Report of findings/Conclusion \\
\hline $\begin{array}{l}\text { Clarke et al. } \\
\qquad(2015)^{9}\end{array}$ & $\begin{array}{l}\text { To evaluate the temporal } \\
\text { tendency of disability; } \\
\text { compare the results between } \\
\text { different types of disability; } \\
\text { and assess the frequency } \\
\text { and nature of the disability. }\end{array}$ & ICD-10 & $\begin{array}{l}60,228 \text { military personnel. } \\
82,877 \text { police officers who had had } \\
\text { at least three years of peacetime } \\
\text { service in the Australian Defense } \\
\text { Force and no experience in } \\
\text { overseas deployment. }\end{array}$ & $\begin{array}{l}\text { Standard deployment time: }<100 \text { days } \\
\text { Deployment time: between } 100-199 \\
\text { days increased the risk of having a mental } \\
\text { illness by } 2.42 \text { ( } 2.24 \text { to } 2.61) \text {; having served } \\
\text { between } 200-364 \text { days increased the risk of } \\
\text { having a mental illness by } 3.27 \text { ( } 3.07-3.50) \text {; } \\
\text { and having served more than } 365 \text { days } \\
\text { increased the risk by } 3.53(3.29-3.79)\end{array}$ \\
\hline Brundage $(2013)^{17}$ & $\begin{array}{l}\text { To estimate the percentages } \\
\text { of female police officers who } \\
\text { were affected by diseases } \\
\text { and injuries between the first } \\
\text { and third deployment. }\end{array}$ & $\begin{array}{l}\text { ICD-9 through } \\
\text { standardized records } \\
\text { (hospitalizations or } \\
\text { outpatient visits) }\end{array}$ & $\begin{array}{c}\text { 154,548 active women who } \\
\text { completed at least one OEF/OIF/ } \\
\text { OND deployment. }\end{array}$ & $\begin{array}{l}\text { Standard deployment time: }<120 \text { days } \\
\text { Deployment time: } 4-6 \text { months increased } \\
\text { the risk of PTSD by } 1.17(10.02-1.34) ; \\
\text { having been deployed between } 6-9 \text { months } \\
\text { increased the risk of PTSD by } 1.57(1.38- \\
1.80) \text {; having been deployed between } 9-12 \\
\text { months increased the risk of PTSD by } 1.73 \\
(1.50-2.0) \text {; and having been deployed for } \\
\text { longer than } 12 \text { months increased the risk of } \\
\text { PTSD by } 2.24(1.95-2.57) \text {. }\end{array}$ \\
\hline Bell et al. $(2011)^{18}$ & $\begin{array}{l}\text { To assess the role of a) } \\
\text { deployment in the combat } \\
\text { zone, b) members of the } \\
\text { elite force, c) previous } \\
\text { hospitalization for mental } \\
\text { illness, d) demographic } \\
\text { factors, and e) the interaction } \\
\text { of these factors in armed } \\
\text { forces discharge with mental } \\
\text { health disability. }\end{array}$ & $\begin{array}{l}\text { Dichotomous variables } \\
\text { for the primary diagnosis of } \\
\text { mental health, substance } \\
\text { abuse, injury, or other } \\
\text { diagnoses. }\end{array}$ & $\begin{array}{l}\text { 4,457 Army soldiers with some } \\
\text { mental disability. Control group of } \\
\text { soldiers with disabilities other than } \\
\text { mental health disabilities }(8,974) . \\
\text { Control group of soldiers without } \\
\text { history of disability }(9,128) .\end{array}$ & $\begin{array}{l}\text { Standard deployment time: not reported } \\
\text { Deployment time: } 1-6 \text { months increases } \\
\text { the risk of disability by } 1.49(1.33,1.66) \text {, } \\
\text { having been deployed between } 7-12 \text { months } \\
\text { increased the risk of disability by } 2.04 \\
(1.84,2.26) \text {, and having been deployed for } \\
13 \text { months or more increased the risk of } \\
\text { disability by } 2.69(2.38,3.04) \text {. }\end{array}$ \\
\hline AFHSC $(2011)^{19}$ & $\begin{array}{l}\text { To evaluate the records of the } \\
\text { experiences of } \\
\text { deployment in with regard to } \\
\text { age, military occupation, and } \\
\text { dwell time between repeated } \\
\text { deployments }\end{array}$ & $\begin{array}{l}\text { ICD-9 through } \\
\text { standardized records } \\
\text { (hospitalizations or } \\
\text { outpatient visits). }\end{array}$ & $\begin{array}{l}\text { Active members of the United } \\
\text { States Armed Forces who returned } \\
\text { from } \\
\text { OEF/OIF/OND deployment during } \\
\text { the study period }\end{array}$ & $\begin{array}{l}\text { Dwell time: The number of soldiers } \\
\text { diagnosed with PTSD and anxiety disorder } \\
\text { increased with the dwell time that preceded } \\
\text { the second and third deployments when } \\
\text { compared with the first deployment; } \\
\text { PTSD was smaller in the fourth and fifth } \\
\text { deployments than in the third deployment. }\end{array}$ \\
\hline $\begin{array}{c}\text { MacGregor } \\
(2014)^{20}\end{array}$ & $\begin{array}{l}\text { To assess the effect of dwell } \\
\text { time and the occurrence } \\
\text { of psychological outcomes } \\
\text { among Navy combatants with } \\
\text { two deployments. }\end{array}$ & $\begin{array}{l}\text { A health screening } \\
\text { questionnaire was used to } \\
\text { identify health problems. }\end{array}$ & $\begin{array}{l}\text { Active members of the United } \\
\text { States Navy, identified from } \\
\text { electronic records, diagnosed with } \\
\text { PTSD and depression. }\end{array}$ & $\begin{array}{l}\text { Dwell time: The mean duration of the first } \\
\text { deployment was } 207 \text { days; of the second, } \\
205 \text { days. The mean dwell time was longer } \\
\text { than the duration of the first deployment, } \\
\text { with a median of } 338 \text { days. The strongest } \\
\text { predictor for both PTSD (OR } 2.28,95 \% \mathrm{Cl} \\
2.00 \text { to } 2.59 \text { ) and depression (OR } 1.30,95 \% \\
\mathrm{Cl} 1.11-1.53 \text { ) was having been exposed to } \\
\text { combat. }\end{array}$ \\
\hline
\end{tabular}


Citation: Santiago Bossert TC, Guerra Júnior, AA, Ruas CM, de Araújo VE, de Assis Acúrcio F, et al. Relationship Between Length of Exposure to Trauma and Mental IIIness in the Police. J Neurol Psychol. 2019; 7(1): 11.

\begin{tabular}{|c|c|c|c|c|}
\hline $\begin{array}{l}\text { O'Toole et al. } \\
\qquad(2009)^{21}\end{array}$ & $\begin{array}{l}\text { To assess the physical and } \\
\text { mental health of veterans } \\
\text { after the war and to compare } \\
\text { them with the Australian } \\
\text { population. To examine the } \\
\text { relationships between military } \\
\text { aspects, service in Vietnam, } \\
\text { and PTSD in veterans. }\end{array}$ & ICD-10 & $\begin{array}{l}450 \text { Australian veterans who were } \\
\text { in combat in Vietnam (case) } \\
\text { General population of Australia } \\
\text { (control). }\end{array}$ & $\begin{array}{l}\text { Standard deployment time: not reported } \\
\text { Deployment time: service durationwas } \\
\text { primarily associated with moderate } \\
\text { depressive disorders (5.61 [1.26-5.04]), and } \\
\text { a diagnosis of PTSD (3.59 [4.48-8.66]), in } \\
\text { the first set of interviews (21.96 years after } \\
\text { the mission). In the second set of interviews } \\
\text { (36.2 years after), recurrent severe } \\
\text { depression (F33.2; } 5.48 \text { [1.23-24.32]), and } \\
\text { diagnosis of PTSD, (3.17 [1.20-8.41]) were } \\
\text { observed. }\end{array}$ \\
\hline $\begin{array}{l}\text { Shen et al } \\
(2009)^{22}\end{array}$ & $\begin{array}{c}\text { To assess whether site } \\
\text { and duration of deployment } \\
\text { influences the incidence of } \\
\text { PTSD. }\end{array}$ & $\begin{array}{c}\text { Diagnosis of PTSD } \\
\text { according to at least two } \\
\text { positive responses in the } \\
\text { PC-PTSD }\end{array}$ & $\begin{array}{l}\text { Police Navy officers who returned } \\
\text { from deployment in the period } \\
\text { between } 2002 \text { and } 2006 \text { and who } \\
\text { completed the post-deployment } \\
\text { health assessment. }\end{array}$ & $\begin{array}{l}\text { Standard deployment time: not reported. } \\
\text { Deployment time: Sailors who were } \\
\text { deployed at least onceduring the } 36 \text { months } \\
\text { had a high probability of having PTSD } \\
(0.5 \%, p<0.01) \text {; between } 61 \text { and } 180 \text { days, } \\
1.1 \% \text { more likely to have been positive for } \\
\text { PTSD, and greater than } 180 \text { days, } 2.2 \% \\
\text { more likely to have been positive for PTSD. }\end{array}$ \\
\hline $\begin{array}{l}\text { Okulate et al } \\
(2006)^{23}\end{array}$ & $\begin{array}{l}\text { To assess the relationship } \\
\text { between exposure to } \\
\text { trauma and duty and onset } \\
\text { of symptoms in individuals } \\
\text { diagnosed with PTSD. }\end{array}$ & $\begin{array}{l}\text { PTSD assessed through a } \\
\text { checklist. }\end{array}$ & $\begin{array}{l}\text { All hospitalized patients who } \\
\text { participated in military operations } \\
\text { over a period of four years (1990- } \\
\text { 1994) and who were physically fit } \\
\text { to be evaluated. }\end{array}$ & $\begin{array}{l}\text { Standard deployment time: not reported. } \\
\text { Deployment time: PTSD was significantly } \\
\text { associated with the time spent in the } \\
\text { combat area }\left(x^{2}=60.93, p<0.00\right) . \text { In } \\
\text { the multivariate regression analysis, } \\
\text { the independent variable that was most } \\
\text { associated with PTSD was time in combat } \\
(p=0.007 \text {, odds ratio (OR) } 3.32,95 \% \mathrm{Cl} \text { : } \\
1.31-4.52) .\end{array}$ \\
\hline Adler $(2005)^{7}$ & $\begin{array}{c}\text { To evaluate the effect } \\
\text { of deployments on the } \\
\text { psychological health of police } \\
\text { officers }\end{array}$ & $\begin{array}{l}\text { SDS, Post-Traumatic } \\
\text { Stress Scale } \\
\text { DSM-IV }\end{array}$ & $\begin{array}{l}\text { United States soldiers in mission in } \\
\text { the Bosnian area of operations. }\end{array}$ & $\begin{array}{l}\text { Standard deployment time: not reported. } \\
\text { Deployment time: Significant relationship } \\
\text { of } 0.10(p<0.01) \text { between the number of } \\
\text { months deployed and increased score on } \\
\text { the depression scale in men. PTSD scores } \\
\text { for men increased with time of deployment }(r \\
=0.14, p<0.01) \text {. }\end{array}$ \\
\hline $\begin{array}{l}\text { Grieger et al. } \\
\qquad(2006)^{24}\end{array}$ & $\begin{array}{c}\text { To examine rates, predictors, } \\
\text { and the incidence of PTSD } \\
\text { and depression. }\end{array}$ & $\begin{array}{l}\text { Patients who met DSM-IV } \\
\text { criteria. }\end{array}$ & $\begin{array}{l}\text { Seriously injured Army soldiers } \\
\text { during and after hospitalization. }\end{array}$ & $\begin{array}{l}\text { Standard deployment time: not reported. } \\
\text { Deployment time: soldiers with longer } \\
\text { exposure to combat were } 4.8 \text { times more } \\
\text { likely to develop PTSD at } 1 \text { month }(95 \% \\
\mathrm{Cl}=1.6-14.4 \text {, Wald } \mathrm{X} 2=7.74, \mathrm{Df}=1, \mathrm{p} \\
=0.005) \text {. Exposure to combat was not } \\
\text { significantly associated with the risk of } \\
\text { PTSD or depression at } 4 \text { or } 7 \text { months. }\end{array}$ \\
\hline $\begin{array}{l}\text { Emsley, et al } \\
(2003)^{25}\end{array}$ & $\begin{array}{l}\text { Evaluate the relationship } \\
\text { between trauma exposure } \\
\text { and the onset of symptoms } \\
\text { in patients diagnosed with } \\
\text { PTSD }\end{array}$ & $\begin{array}{l}\text { Patients who met DSM-IV } \\
\text { criteria }\end{array}$ & $\begin{array}{l}\text { Members of the South African } \\
\text { Security Force permanently retired } \\
\text { due to a diagnosis of PTSD. }\end{array}$ & $\begin{array}{l}\text { Standard deployment time: not reported. } \\
\text { Deployment time: Age was significantly } \\
\text { correlated with service time }(r=0.85, p= \\
0.0001) \text {, exposure to trauma prior to the } \\
\text { onset of symptoms ( } r=0.772, p=0.001) \text {, } \\
\text { presence of a psychiatric disorder }(r= \\
0.20, p=0.03) \text {, and contribution to PTSD } \\
\text { symptoms }(r=0.75, p=0.001) \text {. The } 22 \\
\text { individuals }(18 \%) \text { who reported a delay } \\
\text { in symptom onset following exposure to } \\
\text { trauma had significantly longer police } \\
\text { service time }(t=2.1, d f=33, p=0.048) \text {. }\end{array}$ \\
\hline & $\begin{array}{l}\text { To describe the } \\
\text { characteristics of }\end{array}$ & Mississippi scale & & \\
\hline
\end{tabular}


Citation: Santiago Bossert TC, Guerra Júnior, AA, Ruas CM, de Araújo VE, de Assis Acúrcio F, et al. Relationship Between Length of Exposure to Trauma and Mental IIIness in the Police. J Neurol Psychol. 2019; 7(1): 11.

ISSN: 2332-3469

\begin{tabular}{|c|c|c|c|c|}
\hline $\begin{array}{l}\text { Ross and } \\
\text { Wonders }(1993)^{26}\end{array}$ & $\begin{array}{l}\text { post-traumatic stress in the } \\
\text { military. }\end{array}$ & $\begin{array}{l}\text { based on DSM III-R } \\
\text { criteria }\end{array}$ & $\begin{array}{c}\text { This was a convenience sample, } \\
\text { with voluntary military active and } \\
\text { reserve personnel who had been } \\
\text { deployed to the } \\
\text { Persian Gulf. }\end{array}$ & $\begin{array}{l}\text { Standard deployment time: not reported. } \\
\text { Deployment time: } 3 \text { to } 6 \text { months had mean } \\
\text { PTSD score of } 77.57 \text {; those who were } \\
\text { deployed for more than } 6 \text { months had mean } \\
\text { PTSD score of } 69.86 \text {. }\end{array}$ \\
\hline Branchey $(1990)^{27}$ & $\begin{array}{l}\text { To assess the relationship } \\
\text { between PTSD and two } \\
\text { quantitative aspects of } \\
\text { war trauma: duration and } \\
\text { exposure to combat and } \\
\text { intensity of combat. }\end{array}$ & $\begin{array}{l}\text { PTSD diagnosed through } \\
\text { DSM III. }\end{array}$ & $\begin{array}{l}\text { Individuals who attended an } \\
\text { orthopedic clinic, had participated } \\
\text { in the Vietnam War, and were } \\
\text { referred to a psychological } \\
\text { interview. }\end{array}$ & $\begin{array}{l}\text { Standard deployment time: not reported. } \\
\text { Deployment time: An association was } \\
\text { observed between severe PTSD and the } \\
\text { scores obtained in the Laufer Combat Scale } \\
(p<0.009) \text {, as well as between PTSD } \\
\text { frequency and duration of exposure ( } p< \\
0.008) \text {. An increase in combat intensity } \\
\text { was associated with an increase in PTSD } \\
\text { frequency ( } p<0.01) \text {. Increased duration } \\
\text { of combat and increased intensity of } \\
\text { combat were associated with increased } \\
\text { PTSD frequency ( } p<0.008 \text { and } p<0.01 \text {, } \\
\text { respectively). }\end{array}$ \\
\hline
\end{tabular}

Acronyms and abbreviations; ICD: International Classification of Diseases; DSM: Diagnostic and Statistical Manual of Mental Disorders; CI: Confidence Interval; SDS: Self-Rating Depression Scale; OR: Odds Ratio.

study assessed the percentage of police officers affected by mental illness. The study by also included a police unit from the United States deployed to the same place of combat; however, the researchers only studied PTSD and their aim was to assess whether location and deployment duration influenced PTSD incidence. The shortest deployment duration was studied by, who reported an association with PTSD from 61 days of deployment onwards.

According to the data in (Table 2), some conclusions were presented by the authors of the studies: and defined $<100$ days and $<120$ days, respectively, as the maximum deployment time. The other studies did not define a standard deployment time.

\section{Discussion}

Militarypersonnel need to receive high-performance physical preparation, develop weapon skills, and be psychologically prepared to become capable for overt confrontation (deployment). However, even for those who are well prepared, the length of exposure to deployment is likely to bring direct and indirect consequences to the person and to the unit. In this study, it was possible to determine that one of the main impacts is mental illness, which is often overlooked in the literature.

This statement refers especially to military personnel; of the 905 studies, 890 focused on mental illnesses related to other traumas, predominantly stress, and on other populations such as entrepreneurs, teachers, and politicians. Thus, it is necessary to clarify that although there is academic research addressing mental illnesses arising from traumas and situations of stress, there is a specific lack of studies focusing on the police population.

Among the 13 studies identified, eight were conducted with American military personnel, including veterans and army, navy, air force, and armed forces personnel. The other studies included military personnel from South Africa, Nigeria, and Australia.

The combat zones varied; however, with the exception of the study, which comprised various conflict areas, including police actions and peacekeeping missions, all other studies focused on war zones. The study by had the longest time frame, from 1962 to 1994, assessing Australian military personnel who went to combat in Vietnam. These studies reported the mental illnesses and disabilities that were closely linked to those specified in ICD 10. Thus, although the studies focused on the military population and found a prevalence of mental illnesses, these were not the only focus and were included among other pathologies and limitations caused by war settings.

The studies by focused specifically on the investigation of PTSDs and depression. According to the World Health Organization (WHO, 2017), these are considered milder mental illnesses when compared, for example, to episodes of schizophrenia and bipolar disorder, which are considered as more serious mental illnesses. These other illnesses were also described in the studies by which sought to classify the pathologies according to the ICD-9 guideline, which gave the authors greater possibilities of identifying pathologies.

The studies by associated PTSD incidence with deployment duration; the longer the time of service with exposure to trauma, the greater the delay in the onset of PTSD-related symptoms. In the second study, in which interviews were conducted 36 years after the mission, the diagnosis of PTSD was lower. Most studies focused on assessing the experiences of deployment through questionnaires; this may be a limitation of studies conducted with military personnel, as was previously mentioned.

The studies differ in terms of population and objectives. The earlier study included all police officers in the United States military, whereas the study included only female police officers. The first study aimed to assess deployment and dwell time experiences. In turn, the second study assessed the percentage of police officers affected by mental illness. The study by Shen et al. (2009) also included a military unit from the United States deployed to the same place of combat; however, it only focused on PTSD and the aim was to assess whether location and deployment duration influenced PTSD incidence. The 
Citation: Santiago Bossert TC, Guerra Júnior, AA, Ruas CM, de Araújo VE, de Assis Acúrcio F, et al. Relationship Between Length of Exposure to Trauma and Mental IIIness in the Police. J Neurol Psychol. 2019; 7(1): 11.

ISSN: 2332-3469

Table 4: Assessment of the quality of the articles using the Newcastle-Ottawa scale.

\begin{tabular}{|c|c|c|c|c|c|c|c|c|c|}
\hline \multirow[b]{3}{*}{ Studies } & \multicolumn{8}{|c|}{ Newcastle-Ottawa Scale - Cohort } & \multirow[t]{2}{*}{ Total } \\
\hline & \multicolumn{4}{|c|}{ Selection } & \multicolumn{2}{|l|}{ Comparability } & \multicolumn{2}{|c|}{ Results } & \\
\hline & 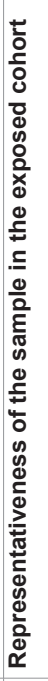 & 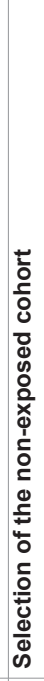 & 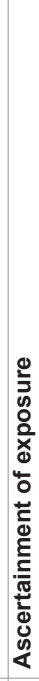 & 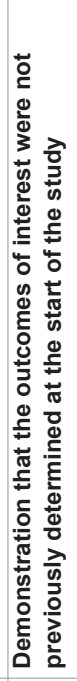 & 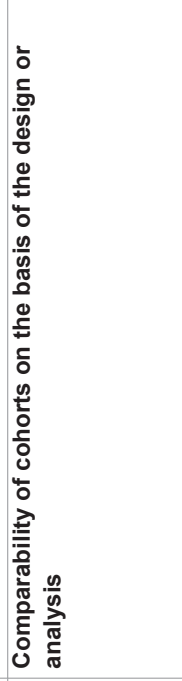 & 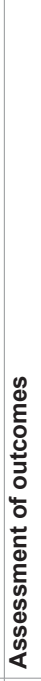 & 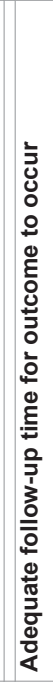 & 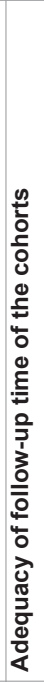 & \\
\hline Clarke et al. (2015) ${ }^{9}$ & 1 & 1 & 1 & 1 & 2 & 1 & 1 & 1 & 9 \\
\hline Brundage $(2013)^{17}$ & 1 & 1 & 1 & 1 & - & 1 & 1 & 1 & 7 \\
\hline O'Toole et al. (2009) ${ }^{21}$ & - & 1 & 1 & 1 & - & - & 1 & - & 4 \\
\hline Shen et al. (2009) ${ }^{12}$ & 1 & 1 & 1 & 1 & - & 1 & 1 & 1 & 7 \\
\hline AFHSC (2011) ${ }^{19}$ & 1 & 1 & 1 & 1 & - & 1 & 1 & 1 & 7 \\
\hline MacGregor (2014) $)^{20}$ & 1 & 1 & 1 & 1 & - & 1 & 1 & 1 & 7 \\
\hline Branchey $(1990)^{27}$ & - & 1 & 1 & 1 & - & - & 1 & 1 & 5 \\
\hline \multicolumn{10}{|c|}{ Newcastle-Ottawa Scale - Case-Control } \\
\hline & \multicolumn{4}{|c|}{ Selection } & Comparability & \multicolumn{3}{|c|}{ Results } & \\
\hline Studies & 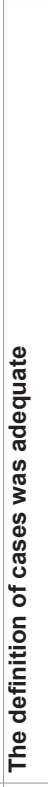 & 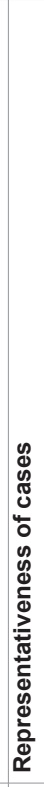 & 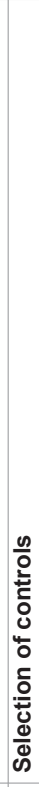 & 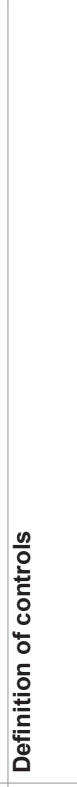 & 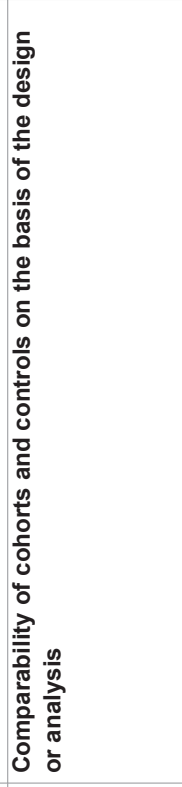 & 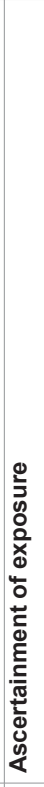 & 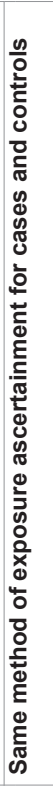 & 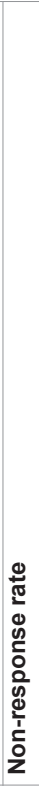 & Total \\
\hline Bell et al. (2011) & 1 & 1 & 1 & 1 & - & 1 & 1 & - & 6 \\
\hline Okulate et al. $(2006)^{23}$ & 1 & 1 & - & - & - & - & 1 & - & 3 \\
\hline
\end{tabular}


Citation: Santiago Bossert TC, Guerra Júnior, AA, Ruas CM, de Araújo VE, de Assis Acúrcio F, et al. Relationship Between Length of Exposure to Trauma and Mental Illness in the Police. J Neurol Psychol. 2019; 7(1): 11.

shortest deployment time was studied by Shen et al. (2009) who found an association with PTSD from 61 days of deployment onwards.

Although the studies present contradictory results in relation to the deployment time that military personnel can withstand without any damage to their mental health, they all agree that the longer the deployment time, the greater the risk and incidence of mental illnesses, and the greater the likelihood of developing more severe pathologies, as shown in the studies. This finding also occurs when the military personnel has a dwell time, i.e., a period at home before another deployment. In this case, and according to, the military personnel begin to show signs of mental illness after the second or third deployment.

An interesting feature was noted in the study by, who stated that police and/or military personnel with longer careers before deployment usually present a later onset of mental pathologies than those less experienced who are exposed to combat.

The following conclusions were presented in the studies: defined $<100$ days and $<120$ days, respectively, as the maximum deployment time that military personnel can withstand. The other studies did not define standard deployment times.

Considering the limitations of reality in terms of police actions in different countries, the minimum exposure time at combat was calculated on the basis of the data presented in those studies. In this perspective, the maximum time officers can be exposed to deployment without developing mental illness would be up to 30 days.

Although the study by presented mental disorders associated with other pathologies resulting from deployment, the remaining studies show that, regardless of the presence of sequelae, military personnel are very prone to developing or having a recurrence of mental illness after deployment.

\section{Final Considerations}

In this review, it was observed that, although military personnel are an essential professional class for the maintenance of social order, requiring good mental health to adequately perform their activities, few studies have investigated the consequences of exposure of these officers to deployment. However, the studies that assessed the consequences of such exposure to mental burden confirmed the occurrence of behavioral mental disorders; the most commonly observed conditions were depression, obsessive disorders, and excessive anxiety.

One possible explanation for the lack of research involving the military is the difficulty in accessing records and data, mainly because of the confidentiality and security protocols adopted by the military organizations.

Of the 905 studies that associated behavioral disorders with stress situations, only 13 addressed the topic of this review and could therefore be included. These 13 studies agree on the existence of an association between exposure to deployment and mental illness onset.

The retrieved data suggested that the longer the military personnel are exposed to deployment, the greater the incidence and prevalence of mental illnesses. These can range from mild to severe in nature. However, most studies focused solely on the research of the relationship between deployment time and mental illness and did not look more deeply into the extent of these diseases, the need for drug therapy, or duration of treatment after the diagnosis of mental illness, whether it was depression or milder behavioral disorders such as anxiety.

In addition to the lack of studies on this population, one of the main limitations of the present review was the lack of studies that describe, in a specific and detailed manner, the diseases, their treatments, and drug therapies, as well as the intrinsic and extrinsic consequences of these conditions to military personnel.

Overall, this study has implications for understanding the causes of post-traumatic stress in the police environment and can help decrease the incidence of stress in the military services. Moreover, this study provides a basis for military leaders to establish programs to improve assessment, prevention, and intervention measures.

Data from this study suggest that military leaders should provide continued support to the personnel during and after deployment, as well as adequate treatment before the problems become chronic and cause damage to society and the military unit. This is especially important with regard to the Brazilian armed forces, because no studies investigating the complications and/or consequences of mental illness after deployment of Brazilian military personnel were retrieved.

\section{References}

1. American Psychiatric Association (1994) Diagnostic and statistical manual of mental disorders ( $4^{\text {th }}$ edn.). Washington, DC pp: 358.

2. Ikin JF, Sim MR, Creamer MC, Forbes AB, McKenzie DP, et al. (2004) War-related psychological stressors and risk of psychological disorders in Australian veterans of the 1991 Gulf War. Br J Psychiatry 185: 116-26.

3. Kang HK, Natelson BH, Mahan CM, Lee KY, Murphy FM (2003) Posttraumatic stress disorder and chronic fatigue syndrome-like illness among Gulf War veterans: a population-based survey of 30,000 veterans. Am J Epidemiol 157: $141-148$.

4. Southwick SM, Morgan CA $3^{\text {rd }}$, Darnell A, Bremner D, Nicolaou AL (1995) Trauma-related symptoms in veterans of operation desert storm: a 2-year follow-up. Am J Psychiatry 152: 1150-1155.

5. Adler AB, Huffman AH, Bliese PD, Castro CA (2005) The impact of deployment length and experience on the well-being of male and female soldiers. J Occup Health Psychol 10: 121-137.

6. National Audit Office (2006) Recruitment and retention in the armed forces. Report by the comptroller and auditor general. HC 1633-1 Session 20052006. London: Ministry of Defense 2006 pp: 1-67.

7. Rona RJ, Fear NT, Hull L, Greenberg N, Earnshaw M (2007) Mental health consequences of overstretch in the UK armed forces: first phase of a cohort study. BMJ 335: 603-610.

8. Barrett DH, Boehmer TK, Boothe VL, Flanders WD, Barrett DH (2003) Health-related quality of life of U.S. military personnel: A population-based study. Mil Med 168, 941-947.

9. Clarke PM, Gregory R, Salomon JA (2015) Care Long-term disability associated with war-related experience among Vietnam veterans retrospective cohort study. Med Care 53: 401-408.

10. Aiken AB, Mahar AL, Kurdyak P, Whitehead M, Groome PA (2016) A descriptive analysis of medical health services utilization of Veterans living in Ontario: a retrospective cohort study using administrative healthcare data. BMC Health Serv Res 351: 1-11.

11. Aldé L (2003) It's all in a day's work: work process and health perceptions on the Medical-Legal institute of Rio de Janeiro. Dissertation. Rio de Janeiro: 
Citation: Santiago Bossert TC, Guerra Júnior, AA, Ruas CM, de Araújo VE, de Assis Acúrcio F, et al. Relationship Between Length of Exposure to Trauma and Mental IIIness in the Police. J Neurol Psychol. 2019; 7(1): 11.

Escola Nacional de Saúde Pública Sérgio Arouca, Fundação Oswaldo Cruz.

12. Bourguignon DR, Borges LH, Brasil APR, Fellipe EV, Milanezi EL, et al. (1998) Analysis of the working and health conditions of Civil Police workers in Espírito Santo. Brazilian J Occupational Health 24: 95-113.

13. Minayo, de Souza Souza (MC), Ramo E (2003) Mission Investigate: between the ideal and the reality of being a police officer. Rio de Janeiro: Garamond.

14. Minayo MC, de Assis SG, de Oliveira RV (2011) The impact of the professional activities on the physical and mental health of civilian and military police officers in Rio de Janeiro. Ciência Saúde Coletiva 16: 2199-2209.

15. Booth-Kewley S, Larson GE, Highfill-McRoy RM, Garland CF, Gaskin TA (2010) Correlates of post-traumatic stress disorder symptoms in Marines back from war. J Trauma Stress 23: 69-77.

16. Stroup DF, Berlin JA, Morton SC, Olkin I, Williamson GD (2000) Metaanalysis of observational studies in epidemiology: a proposal for reporting. Meta-analysis Of Observational Studies in Epidemiology (MOOSE) group. JAMA 283: 2008-2012.

17. Bell NS, Hunt PR, Harford TC, Kay A (2011) Deployment to a combat zone and other risk factors for mental health-related disability discharge from the U.S. Army: 1994-2007. J Trauma Stress 24: 34-43.

18. Shen YC, Arkes J, Pilgrim J (2009) The effects of deployment intensity on post-traumatic stress disorder: 2002-2006. Mil Med 174: 217-223.

19. MacGregor AJ, Heltemes KJ, Clouser MC, Han PP, Galarneau, MR (2014) Dwell time and psychological screening outcomes among military service members with multiple combat deployments. Mil Med 179: 381-387.
20. Armed Forces Health Surveillance Center (AFHSC) (2012) Health of women after wartime deployments. correlates of risk for selected medical conditions among females after initial and repeat deployments to Afghanistan and Iraq, active component, U.S. Armed Forces. MSMR 19: 2-10.

21. O'Toole BI, Catts SV, Outram S, Pierse KR, Cockburn J (2009) The physical and mental health of Australian Vietnam veterans 3 decades after the war and its relation to military service, combat, and post-traumatic stress disorder. Am J Epidemiol 170: 318-330.

22. Okulate GT, Jones OB (2006) Post-traumatic stress disorder, survivor guilt and substance use - a study of hospitalised Nigerian army veterans. SAMJ 96: 144-146.

23. Ross MC, Wonders J (1993) An exploration of the characteristics posttraumatic stress disorder in reserve forces deployed during desert storm. Arch Psychiatr Nurs 7: 265-269.

24. Armed Forces Health Surveillance Center - AFHSC (2011) Associations between repeated deployments to Iraq (OIF/OND) and Afghanistan (OEF) and post-deployment illnesses and injuries, active component, U.S. Armed Forces, 2003-2010. Part II. Mental disorders, by gender, age group, military occupation, and "dwell times" prior to repeat (second through fifth) deployments. MSMR 18: 1-19

25. Grieger TA, Cozza SJ, Ursano RJ, Hoge C, Martinez PE (2006) Posttraumatic stress disorder and depression in battle-injured soldiers. Am J Psychiatry 163: 1777-1783.

26. Buydens-Branchey L, Noumair D, Branchey M (1990) Duration and intensity of combat exposure and posttraumatic stress disorder in Vietnam veterans. J Nerv Ment Dis 178: 582-587.

27. Emsley RA, Seedat S, Stein DJ (2003) Posttraumatic stress disorder and occupational disability in South African security force members. J Nerv Ment Dis 191: 237-241. 